\title{
OROBANCHE PALLIDIFLORA WIMM. \& GRAB. IN POLAND: DISTRIBUTION, HABITAT AND HOST PREFERENCES
}

\author{
RenATA PiWOWARCZYK ${ }^{1}$, Piotr CHMIELEWSKI ${ }^{2}$, BŁAŻEJ GIERCZYK ${ }^{3}$, \\ BARTOSZ PIWOWARSKI ${ }^{4}$, PRZEMYSŁAW STACHYRA ${ }^{5}$ \\ ${ }^{1}$ Department of Botany, Institute of Biology, \\ Jan Kochanowski University in Kielce \\ Świętokrzyska 15, 25-406 Kielce, Poland \\ e-mail: renka76@wp.pl \\ 2 Zamość Natural Society \\ Partyzantów 74/59, 22-400 Zamość, Poland \\ ${ }^{3}$ Faculty of Chemistry, Adam Mickiewicz University, \\ Grunwaldzka 6, 60-780 Poznań, Poland \\ ${ }^{4}$ Department of Plant Taxonomy and Phytogeography, \\ Institute of Botany, Jagiellonian University \\ Kopernika 27, 31-501 Kraków, Poland \\ ${ }^{5}$ Roztoczański National Park \\ Plażowa 2, 22-470 Zwierzyniec, Poland
}

(Received: September 23, 2009. Accepted: December 30, 2009)

\begin{abstract}
The paper presents ten new localities of Orobanche pallidiflora Wimm. \& Grab. from Poland (Middle Roztocze, Równina Bełska plain, Wyżyna Malopolska upland, Góry Kaczawskie Mts and Western Bieszczady Mts). Information on hosts, abundance and habitat preferences at the new localities is given and a supplemented map of the distribution in Poland is included.
\end{abstract}

KEY WORDS: Orobanche pallidiflora, habitat, distribution, host, Poland.

\section{INTRODUCTION}

Orobanche pallidiflora Wimm. \& Grab. belongs to the parasitic family Orobanchaceae L. and is one of the rarest elements of the Polish flora. It is considered to be rare (R) in Poland (Zarzycki and Szeląg 2006), endangered (EN) in Lower Silesia (Kącki et al. 2003), the Sudetes (Fabiszewski and Kwiatkowski 2002), Western Pomerania (E) (Żukowski and Jackowiak 1995) and critically endangered (CR) in Gdańskie Pomerania (Markowski and Buliński 2004). Its threat status is indeterminate (I) in the Kujawy and Pomerania region (Rutkowski 1997) and Upper Silesia (Parusel et al. 1996), and it is thought to be regionally extinct in the Opole province (RE) (Nowak et al. 2003; Nowak et al. 2008). O. pallidiflora is listed as a strictly protected species (Regulation of the Minister of Environment of 24th July 2004).

\section{TAXONOMY}

Syn.: Orobanche pallidiflora Wimmer et Grabowski 1829 - Orobanche reticulata Wallr. subsp. pallidiflora (Wimm. et Grab.) Hayek; O. reticulata var. pallidiflora (Wimm. et Grab.) G. Beck; O. cirsii Fries; O. procera Koch; O. platystigma Reichenb.

$O$. pallidiflora belongs to the section Osproleon Wallr., grex Glandulosae G. Beck (Beck 1890, 1930). Species belonging to the grex Glandulosae are mostly characterised by a cover of dark, usually purple or violet glandular hairs, sometimes sitting on small warts, on the upper corolla lip, which makes the corolla appear darkly spotted (Beck 1890, 1930). Orobanche alba Stephan ex Willd. also belongs to the grex in Poland. The species is differently treated in various studies: as a separate taxon or in the rank of subspecies or variety within Orobanche reticulata $(O$. reticulata Wallr. subsp. pallidiflora (Wimm. et Grab.) Hayek, O. reticulata var. pallidiflora (Wimm. et Grab.) G. Beck) (Beck 
1890, 1930; Gilli 1966; Chater and Webb 1972; Kreutz 1995; Zázvorka 2000; Rothmaler et al. 2002).

$O$. reticulata and $O$. pallidiflora differ in morphology, habitat and altitudinal ranges as well as host preferences. The former is associated with southern Europe: high parts of the Alps, NE Spain and E France (the Pyrenees), Italy, Baltic states and Greece. It is known in Asia from the Caucasus and the Himalayas (Kreutz 1995; Meusel et al. 1978). It is a montane or subalpine species that occurs at altitudes between 1400 and 2500 in the Alps, 1550 and 2000 in the Apennines and up to $3660 \mathrm{~m}$ in the Himalayas (Uhlich et al. 1995). O. pallidiflora is mostly a lowland species and rarely a subalpine species. The most important traits distinguishing the two problematic species are given in Table 1 below following the keys by Beck $(1890,1930)$, Kreutz (1995), Rothmaler et al. (2002).

The altitudinal gradient can cause plastic differences in morphology of the species, especially in colour, glandulosity or biometric features, and may result in the selection of different hosts that are also related to specific altitudinal ranges and habitats. While they may be only ecological varieties of the same taxon, especially as regards different hosts, the altitudinal gradient and morphological characters, morphological and ecological characters seem to be important and conspicuous enough to separate the two species. However, further research into both taxa, including molecular studies, is recommended.

\section{GENERAL DISTRIBUTION}

Orobanche pallidiflora occurs as a rare or even sporadic species in flatland regions of Europe (less frequently in subalpine regions), ranging from France in the west, Central and Southern Europe, to the Ural Mts and the Caucasus, and from Asia Minor up to the Himalayas (Mądalski 1967; Foley 1993; Kreutz 1995). As approaches to the taxon are inconsistent, it is difficult to specify the exact distribution of $O$. pallidiflora in Europe. The species is often treated inclusively within $O$. reticulata. $O$. pallidiflora is widespread and its range is discontinuous; its localities, however, are rare. It is included into species with a EuropeanWestern Siberian range (Rothmaler et al. 2002). Its groups are usually quite numerous where it occurs (Kreutz 1995).

\section{DISTRIBUTION IN POLAND}

The species is known from only a few localities in Poland, mainly from Western and Eastern Pomerania, Lower Silesia and the Sudetes (Zając and Zając 2001) (Fig. 1). It has also been reported from the Wyżyna Lubelska upland, Opole and Roztocze (Szafer et al. 1924; Mądalski 1967).

It has been confirmed at only 41 localities situated in 14 ATPOL cartogram units of 10×10 km squares (Zając 1978) after 2000: 7 localities in the Western Sudetes (Kwiatkowski 2000, 2001, 2005; Bacieczko and Myśliwy 2008), 31 in Szczecin Pomerania (Bacieczko 2002; Bacieczko and Myśliwy 2005, 2008), 1 in the Lower Vistula valley (Rutkowski unpbl.; Zając and Zając 2001), 2 in the Puszcza Romincka Forest (Łachacz 2002) (Fig. 1).

\section{HABITAT AND PHYTOCOENOTIC PREFERENCES}

Orobanche pallidiflora grows mainly in xerothermic and semidry grasslands, on field edges, in different ruderal habitats, in waterlogged alkaline meadows (eutrophic and stony), in humid forest communities and scrub (Mądalski 1967; Tzvelev 1981; Kreutz 1995). According to Zarzycki et al. (2002), it requires moderately warm climatic and light conditions, and has a wide spectrum of soil selection from dry to fresh and moist soils, usually mesotrophic, alkaline, mostly sandy clays and silty formations, poor in organic matter.

The species is usually reported in Europe from communities of the class Artemisietea vulgaris, Mesobromion alliance and the order Molinietalia (Rothmaler et al. 2002).

It usually occurs in variously degraded meadow communities of the class Molinio-Arrhenatheretea, both in humid meadow forms belonging to Calthion palustris and fresh meadows of the Arrhenatherion elatioris alliance in Szczecin Pomerania in Poland. It also grows in typically anthropogenic habitats, especially nitrophilous and ruderal communities of the class Artemisietea vulgaris. It has been reported from roadsides, fallows, banks of water bodies, ecotonal zones between, for instance, water bodies or rushes and fields, fallows or trampled sites, rushes, i.e. Phragmitetum australis beds, rush and sedge beds, for instance Caricetum acutiformis (Bacieczko and Myśliwy 2005, 2008).

TABLE 1. A comparison of the most important diagnostic features of Orobanche pallidiflora and Orobanche reticulata.

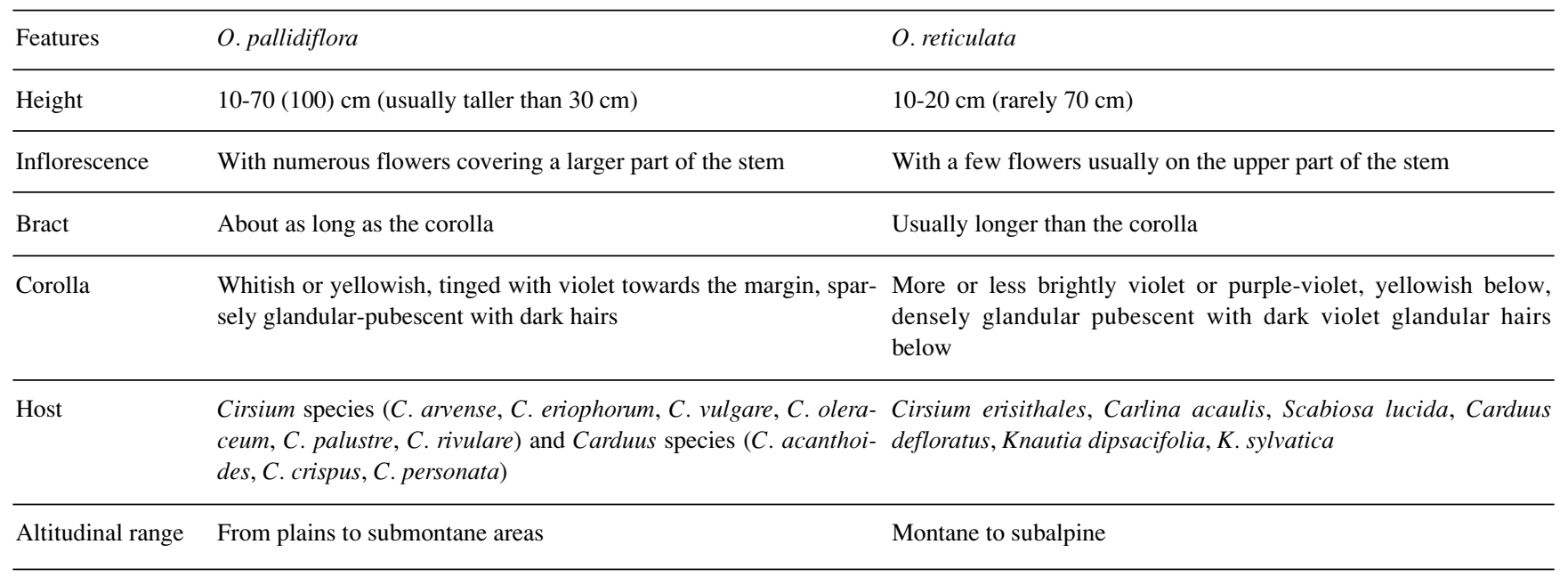




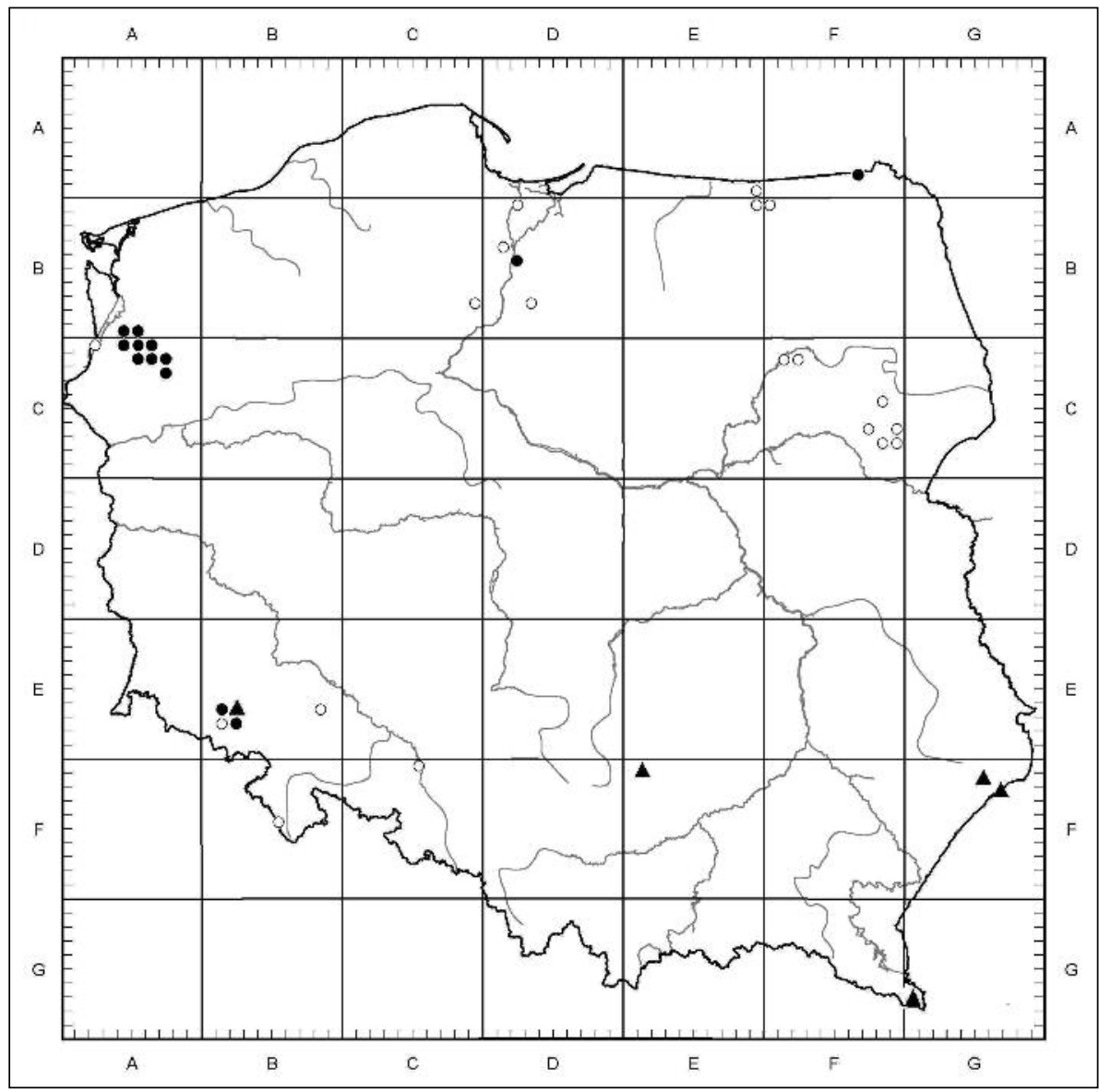

Fig. 1. Distribution of Orobanche pallidiflora Wimm. \& Grab. in Poland (after Zając and Zając 2001, in ATPOL grid 10×10 km, modified and supplemented); $\boldsymbol{\Delta}$ - new localities, - presently existing localities, $\bigcirc$ - locality not confirmed at present, probably extinct.
It grows in a fertile and humid anthropogenic habitat in patches of Carduetum personatae Hadač et al. 1969, a montane nitrophilous community of herbaceous scrub, near Rudawy Janowickie in the Western Sudetes. A high percentage of nitrophilous species, especially of the Aegopodion podagrariae alliance, or meadow species of the order Molinietalia, is observed in this habitat (Kwiatkowski 2005).

The species occurs on low hills with closed quarries or excavation pits in the calcareous part of the Góry Kaczawskie Mts between Wojcieszów and Bolków. It forms a floristically rich xerothermic grassland of the order Brometalia erecti. It has been recorded in humid meadows (Molinietalia) or in carrs in the mountains less frequently (Kwiatkowski 2001).

In NE Poland in the Puszcza Romincka Forest, it occurs in a soligenic baltic mire of the class Scheuchzerio-Caricetea nigrae on the slopes of a copula surrounded by a fen overgrown with reed beds on peat-muck soils with a high iron oxide content and in drier parts of a sloping mire overgrown with a pinewood with a high share of Betula pubescens (Łachacz 2002).

\section{METHODS}

Ten new localities of the species were found in the Middle Roztocze, the Równina Bełska plain, the Wyżyna Małopolska upland, the Góry Kaczawskie Mts and the Western Bieszczady Mts during floristic studies conducted between 2005 and 2009 (Fig. 1). A list of localities was mapped in the network of ATPOL cartogram units of $1 \times 1 \mathrm{~km}$ squares (Zając 1978). The nomenclature of the vascular plant species listed in the phytosociological table follows Mirek et al. (2002) and the nomenclature of syntaxa is used after Matuszkiewicz (2006).

The location of the sites, abundance of individuals within populations and preferred hosts are provided and habitat data are briefly discussed below. Plant communities with Orobanche pallidiflora are presented in Table 2.

Herbarium specimens are deposited in the Herbarium of the Department of Botany, Jan Kochanowski University in Kielce (KTC).

\section{RESULTS}

\section{A LIST OF NEW LOCALITIES OF OROBANCHE PALLIDIFLORA}

\section{Góry Kaczawskie Mts, Nowe Rochowice}

Location: on the left side of the road from the Nowe Rochowice village towards the E65 road, ca. $200 \mathrm{~m}$ from the junction (altitude 495 m, GPS: N 5056 24/E 1602 10).

Habitat: Humid usable and pastured hay meadow, ca. 500-700 $\mathrm{m}^{2}$ and a ditch between the meadow and the road, tall-herb Filipendulo-Geranietum community with a high share of hygrophilous species of the Calthion alliance; high content of $\mathrm{CaCO}_{3}$ in the substrate.

Abundance: 2005 - 60 shoots (in the entire area); $2006-$ 5 shoots (in a ditch, meadow mown); 2007 - 19 shoots (in the entire area, meadow partly mown); 2008 - 35 shoots (in the entire area). 
Host: Cirsium oleraceum. ATPOL: BE 6242.

vid. B. Gierczyk, 2005-2008, det. B. Gierczyk \& R. Piwowarczyk.

\section{Western Bieszczady Mts, Wołosate}

Location: the Bieszczady National Park, by the red tourist hiking trail from Wołosate towards the Przełęcz Bukowska pass (alt. 995 - 1205 m, GPS: N 4903 22/E 2245 40).

Habitat: stony roadside of a metalled road, felled site, tall-herb communities of the Adenostylion alliariae alliance with a high quantitative share of dicotyledonous perennials of the class Molinio-Arrhenatheretea. It was also recorded near the road in a meadow with an abundant share of Carduus personata. The species also enters further areas, strongly shaded sites, adjacent carrs with dominant Alnus incana, with an admixture of mostly Picea abies and Acer pseudoplatanus; the population occurs intermittently in a section of $1,5 \mathrm{~km}$.

Abundance: 2005 - 19 shoots; 2006 - 27; 2007 - 25; 2008 - 223, 2009 - about 1000.

Host: Carduus personata and Cirsium oleraceum. ATPOL: GG 7014.

vid. B. Gierczyk \& J. Soboń, 2005-2008, leg. R. Piwowarczyk, 14.08.2009 (KTC).

\section{Middle Roztocze, Przeorsk (1)}

Location: a fallow descending to the bottom of a small dry valley entering the Sołokija river lying between calcareous hills, by the road from Przeorsk towards Jarczów (NE of the Przeorsk village), (alt. 275 m, GPS: N 50 25 27/E 2330 59).

Habitat: degenerated, slightly humid meadow and fallow in the Sołokija river valley of the class Molinio-Arrhenatheretea bordering with arable fields and xerothermic grasslands, with a high share of segetal species of the class Stellarietea mediae and ruderal species of the classes Artemisietea vulgaris and Agropyretea intermedio-repentis, with a SW exposure, on argillaceous soil.

Abundance: 2007 - 30 shoots, 2008 - 2.

Host: Cirsium arvense.

ATPOL: GF 1550.

leg. P. Chmielewski \& R. Piwowarczyk, 09.06.2007 (KTC).

\section{Middle Roztocze, Przeorsk (2)}

Location: ca. $400 \mathrm{~m}$ E of the buildings in the Przeorsk village on the SW slope of the Łysa Góra hill (alt. $265 \mathrm{~m}$, GPS: N 5025 14/E 2330 59).

Habitat: arable fields, most probably previously used for cereal crops, with a share of segetal species of the class Stellarietea mediae and ruderal species of the class Artemisietea vulgaris.

Abudance: 2007 - four shoots, 2008 - one shoot.

Host: Cirsium arvense.

ATPOL: GF 1560.

leg. P. Chmielewski \& R. Piwowarczyk, 09.06.2007 (KTC).

\section{Równina Bełska plain, Wierzbica}

Location: by a dirt road ca. $1 \mathrm{~km} \mathrm{SW}$ of the Wierzbica village near Machnów Nowy (alt. 215 m, GPS: N 5020 35/E 2339 08).
Habitat: on the edge of a weed-grown field cultivation bordering on humid meadows and pastures in the Sołokija river valley, with a mosaic of meadow species of the class Molinio-Arrhenatheretea, ruderal species of the classes Artemisietea vulgaris and Agropyretea intermedio-repentis and segetal species of the class Stellarietea mediae.

Abundance: 2007 - three shoots (the locality was damaged by field works in spring 2008).

Host: Cirsium arvense.

ATPOL: GF 2631.

vid. P. Stachyra, 2007, leg. P. Chmielewski, 22.09.2007 (KTC), det. R. Piwowarczyk, 2008.

\section{Równina Bełska plain, Kolonia Jarczów I (1)}

Location: E part of the Kolonia Jarczów I village, in a 0.5 ha fallow lying by a field road towards $\mathrm{N}$ of the Wierszczyca village (alt. 235 m, GPS: N 5026 13/E 2334 43).

Habitat: edge of a fallow and a field road between cereal crops, S exposure. Ruderal and segetal species of the classes Artemisietea vulgaris, Agropyretea intermedio-repentis and Stellarietea mediae dominate the community.

Abundance: five specimens.

Host: Cirsium arvense.

ATPOL: GF 1535.

leg. P. Chmielewski \& R. Piwowarczyk, 13.07.2008 (KTC).

\section{Równina Bełska plain, Kolonia Jarczów I (2)}

Location: ca. $750 \mathrm{~m}$ W of the previous location in Kolonia Jarczów I (1), near rural buildings in an abandoned farm overgrown with ruderal vegetation (alt. 238, GPS: N 5026 14,1/E 2334 02,1; N 5025 15/E 2333 57,2).

Habitat: a community with a high share of ruderal species of the classes Artemisietea vulgaris and Agropyretea intermedio-repentis and meadow species of the class Molinio-Arrhenatheretea.

Abundance: 2009 - 4 shoots.

Host: Cirsium arvense.

ATPOL: GF 1544.

leg. det. P. Chmielewski, 20.08.2009, rev. R. Piwowarczyk, 2009.

\section{Równina Bełska plain, Korhynie}

Location: ca $250 \mathrm{~m}$ NE of the village road from Przeorsk to Korhynie, near abandoned farm buildings overgrown with ruderal vegetation (alt. 272 m, N 5024 39,1/E 2331 $53,1)$.

Habitat: a community with a high share of ruderal species of the classes Artemisietea vulgaris and Agropyretea intermedio-repentis and meadow species of the class Molinio-Arrhenatheretea.

Abundance: 2009 - seven shoots.

Host: Cirsium arvense.

ATPOL: GF 1561.

leg. det. P. Chmielewski, 20.08.2009, rev. R. Piwowarczyk, 2009.

\section{Równina Bełska plain, Żurawce}

Location: the northern part of the "Żurawce" ecological site, ca. $1200 \mathrm{~m} \mathrm{~N}$ of the Żurawce village, SW exposure (alt. 280 m, GPS: N 5023 49/E 2333 19).

Habitat: previously used to store artificial fertilisers; at present mostly colonised by ruderal vegetation of the class 


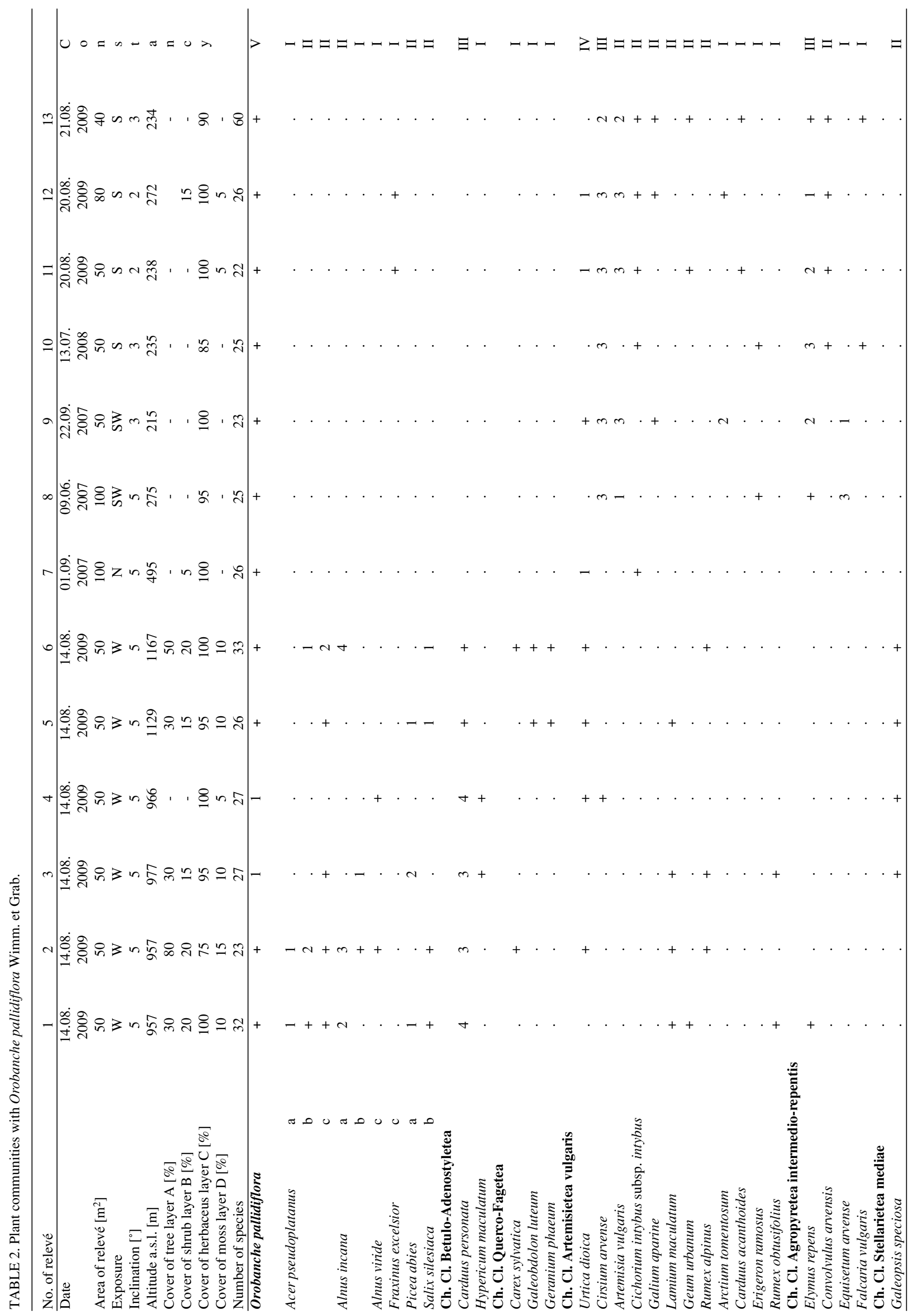




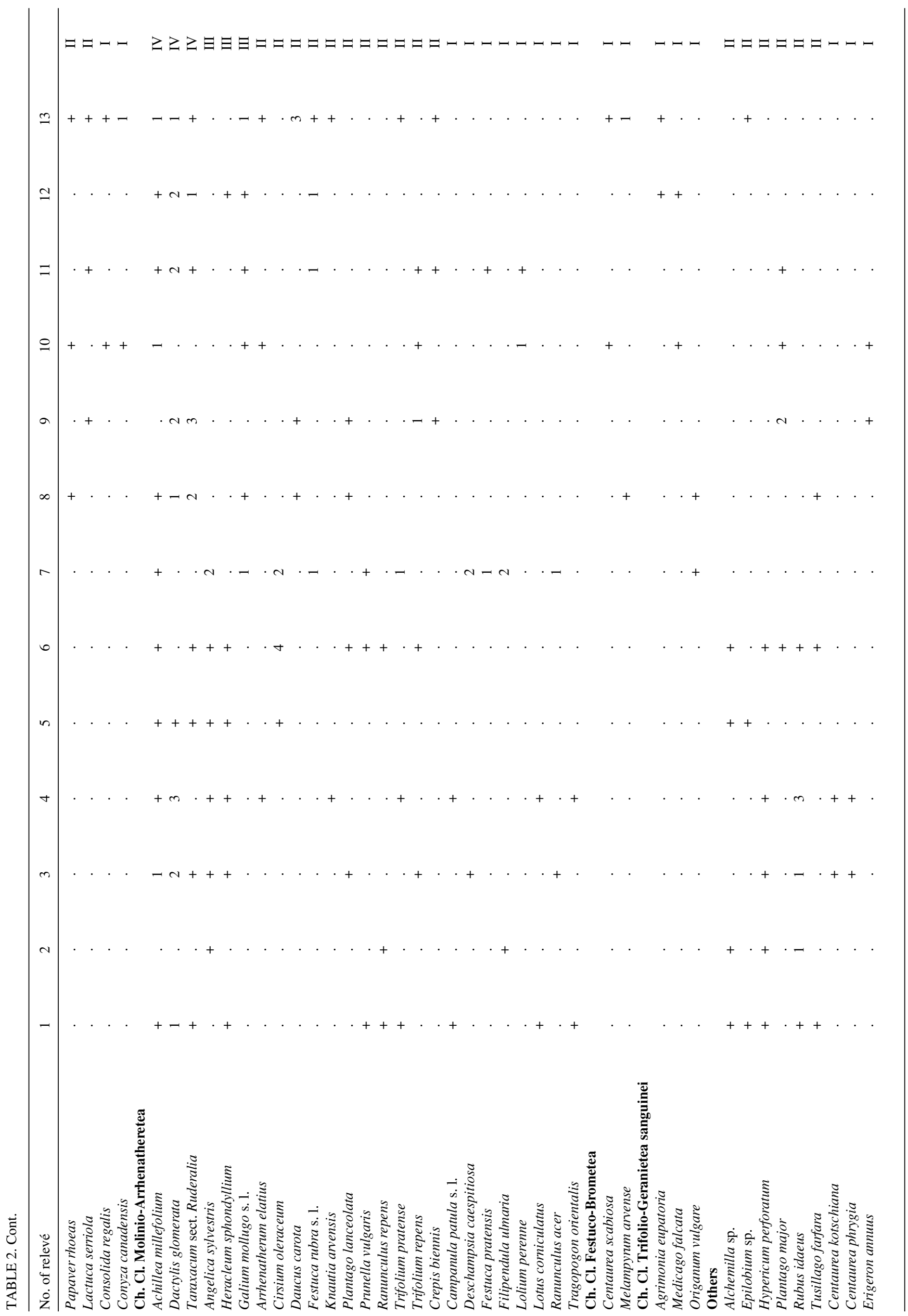


Artemisietea vulgaris and meadow vegetation of the class Molinio-Arrhenatheretea.

Host: Cirsium arvense.

Abundance: four specimens.

ATPOL: GF 1583.

vid. P. Chmielewski \& K. Barańska, 07.10.2009.

\section{Wyżyna Małopolska upland, Jędrzejów Plateau,} Potok Mały

Location: on top of the escarpment between the Potok Mały village and the Mierzawa river; $200 \mathrm{~m} \mathrm{~S}$ of the last buildings in Potok Mały. The locality is $500 \mathrm{~m} \mathrm{~W}$ of the E77 road (alt. 234 m, GPS: N 5035 13/E 2013 36).

Habitat: fallow land on shallow rendzina with a large amount of skeletal parts, on a chalky substrate. A community patch covering $40 \mathrm{~m}^{2}(10 \times 4 \mathrm{~m}), \mathrm{S}$ exposure, bordering on a cereal field on one side and a xerothermic grassland belonging to Thalictro-Salvietum pratensis, which creates a mosaic of species of the class Festuco-Brometea, weeds of cereal crops of the class Stellarietea mediae, ruderal species of the class Artemisietea vulgaris and meadow species of the class Molinio-Arrhenatheretea.

Abundance: 30 individuals.

Host: Cirsium arvense.

ATPOL: EF 0166.

leg. B. Piwowarski, 15.07.2009, leg. det. R. Piwowarczyk, 21.08.2009 (KTC).

\section{CONCLUSIONS}

Orobanche pallidiflora is one of the rarest and highly endangered elements of the Polish flora. It has been recorded only at 51 localities situated in 18 ATPOL cartogram units of $10 \times 10 \mathrm{~km}$ squares (Zając 1978) after 2000: 7 localities in the Western Sudetes, 31 in Szczecin Pomerania, 1 in the Lower Vistula Valley, 2 in the Puszcza Romincka Forest, and at 10 new localities: 1 in the Western Sudetes Mts, 1 in the Western Bieszczady Mts, 7 in the
Równina Bełska plain and Middle Roztocze, and 1 in the Wyżyna Małopolska upland (Fig. 1). The present sites are the south-easternmost localities in Poland.

$O$. pallidiflora is characterised by a broad and variable flowering spectrum. The flowering optimum was mostly observed from July until August (September). Sometimes secondary flowering occurred in late October and early November, especially in the Równina Bełska plain.

As a polyphagous parasite, $O$. pallidiflora feeds on many hosts. Polyphagous species of the genus Orobanche, including $O$. pallidiflora, usually feed on hosts belonging to one family and even to the same genus. $O$. pallidiflora prefers species of the genera Cirsium and Carduus. It usually parasitises Carduus personata and less frequently Cirsium oleraceum at the localities in Rudawy Janowickie Mts in the Sudetes (Kwiatkowski 2005). Host species of the genus Cirsium $(C$. arvense, $C$. palustre, $C$. oleraceum, $C$. vulgare) and Carduus acanthoides have been reported at the localities between Wojcieszów and Bolków (Kwiatkowski 2000, 2001, 2005). It parasitises Cirsium oleraceum in the Puszcza Romincka Forest (Łachacz 2002) and mainly Cirsium arvense or sporadically $C$. oleraceum and C. palustre in Szczecin Pomerania (Celiński 1964; Bacieczko 1984, 1991, 1995, 2002; Bacieczko and Myśliwy 2005, 2008). It parasitises Cirsium arvense in the Równina Bełska plain, Middle Roztocze and Wyżyna Małopolska upland, $C$. oleraceum in the Góry Kaczawskie Mts and Carduus personata or sporadically Cirsium oleraceum in the Western Bieszczady Mts at the present localities.

Population abundance at individual localities fluctuates and the species sometimes does not occur annually. Population abundance in the Western Sudetes was estimated at 200 flowering individuals in Rudawy Janowickie Mts (Kwiatkowski 2005) and ranged from ca. ten to over 300 individuals at the localities between Wojcieszów and Bolków (Kwiatkowski 2001, 2005). A total of ca. 300 individuals were recorded in the Puszcza Romincka Forest (Łachacz 2002) although a more numerous occurrence was al-

Sporadic species: Ch. Cl. Betulo-Adenostyletea: Anthriscus nitida 2; Calamagrostis villosa 1(1); Chaerophyllum hirsutum 1(1); Orobanche flava 5(1); Petasites albus 4(5); Senecio nemorensis gr. 3; Ch. Cl. Querco-Fagetea: Alnus incana C 2; Astrantia major 6; Impatiens noli-tangere 2; Lysimachia nemorum 6; Mercurialis perennis 5; Milium effusum 8; Primula elatior 3; Stachys sylvatica 6; Ch. Cl. Artemisietea vulgaris: Aegopodium podagraria 12(3); Anthriscus sylvestris 12(1); Arctium tomentosum 9(2); Ballota nigra 12; Chaerophyllum aromaticum 7(2); Cirsium vulgare 9; Cynoglossum officinale 13; Echium vulgare 13; Glechoma hederacea 5; Linaria vulgaris 13; Melandrium album 13; Melilotus officinalis 10(1); Rubus caesius 7(1); Ch. Cl. Stellarietea mediae: Aetchusa cynapium subsp. agrestis 9; Anagallis foemina 13, Anthemis arvensis 13; Apera spica-venti 13; Atriplex patula 9; Caucalis daucoides 13; Chenopodium album 9; Elymus hispidus 8; Euphorbia exigua 13; Geranium dissectum 13; Lamium purpureum 12; Lathyrus tuberosus 10; Matricaria maritima subsp. inodora 13; Myosotis arvensis 8; Papaver argemone 10; Polygonum aviculare 13; Rhinanthus serotinus 8; Sinapis arvensis 13; Sonchus arvensis 10; Stachys annuua 13; Veronica persica 13; Vicia hirsuta 8; Viola arvensis 13; Ch. Cl. Molinio-Arrhenatheretea: Bromus hordeaceus 7; Centaurea jacea 1; Cirsium canum 7(1); C. rivulare 9; Colchicum autumnale 7(2); Geranium palustre 7(2); G. pratense 12(1); Lathyrus pratensis 4; Leucanthemum vulgare 4; Lychnis flos-cuculi 7(1); Myosotis palustris 2; Phleum pratense 9; Poa pratensis 7; Potentilla anserina 9(3); Trifolium hybridum s.1. 9; Valeriana officinalis 7(2); Vicia cracca 10; Ch. Cl. Festuco-Brometea: Allium oleraceum 13; Asperula cynanchica 13; Hieracium bauhinii 8; Poa compressa 13; Salvia verticillata 13(1); Ch. Cl. Trifolio-Geranietea sanguinei: Astragalus glycyphyllos 8; Coronilla varia 13; Vicia sylvatica 7; V. tenuifolia 13; Others: Ajuga reptans 5; Alchemilla acutiloba 7; Allium victorialis 2; Alnus viride B 3(1); Athyrium filix-femina 2; Camelina microcarpa subsp. sylvestris 13; Carex panicea 4; Cerasus vulgaris C 12; Cerinthe minor 13; Chamaenerion angustifolium 6; Crataegus monogyna C 13; Epilobium ciliatum 10; Erigeron acer 8; Eupatorium cannabinum 1; Euphorbia esula 13; Fragaria vesca 6; Fraxinus excelsior B 12(1); Galium sp. 5; Gentiana asclepiadea 6; Geum rivale 2; Hypericum perforatum 8; Melandrium rubrum 3; Muscari comosum 10; Picea abies B 6; Pimpinella saxifraga 13; Pinus sylvestris C 12; Poa annua 1; Prunus spinosa C 13; Rosa sp. B 1, C 1(1); Rubus caesius 13; R. hirtus 6; Salix sp. A 5(2); Sambucus nigra B 12(1); S. nigra C 12; Sanguisorba minor 13; Scrophularia scopoli 5; Sedum maximum 13; Senecio jacobaea 13(2); Silene vulgaris 5; Sorbus aucuparia B 2; Stachys alpina 4; Stellaria graminea 4 ; Thymus pulegioides 1 .

Localities of records: 1-6. Western Bieszczady Mts: Wołosate; 7. Góry Kaczawskie Mts: Nowe Rochowice; Middle Roztocze: 8. Przeorsk; Małe Polesie: Równina Bełska plain: 9. Wierzbica, 10. Kolonia Jarczów I (1), 11. Kolonia Jarczów I (2), 12. Korhynie; 13. Malopolska Upland: Jędrzejów Plateau: Potok Mały. 
so observed in some years. Between a few and over 150 individuals were recorded in Szczecin Pomerania (Bacieczko and Myśliwy 2005). Populations were quite sparse in the Równinia Bełska plain and Middle Roztocze, and comprised from a few to ca. 30 individuals. The population in Nowe Rochowice has ranged between five and 60 individuals in the last few years. The abundance, the area colonised and the altitude of the population in the Bieszczady is clearly expanding. From 19 to 223 individuals were gradually recorded between 2005 and 2009, and a mass occurrence of the species was recorded in 2009, when ca. 1000 individuals were observed. It is the most abundant locality in Poland.

The locality in the Western Bieszczady Mts is the highest site of the occurrence of $O$. pallidiflora in Poland recorded so far $(995-1205 \mathrm{~m})$. In the Western Sudetes, the species was recorded at altitudes ranging from 380 to 550 between Wojcieszów and Bolków (Kwiatkowski 2000, 2001), at an altitude of ca. $420 \mathrm{~m}$ in Rudawy Janowickie Mts (Kwiatkowski 2005) and $495 \mathrm{~m}$ in Nowe Rochowice. The altitudinal range was between 235 and $275 \mathrm{~m}$ in the Równina Bełska plain and Middle Roztocze, and $234 \mathrm{~m}$ in the Wyżyna Małopolska upland.

In the Równina Bełska plain and Middle Roztocze, $O$. pallidiflora chooses mostly meadow communities of the class Molinio-Arrhenatheretea, often degraded and humid. It belongs to ecotonal communities, i.e. borders of meadows, fields and fallows. These sites are often disturbed, eutrophied, with a high share of nitrophilous, segetal and ruderal species, especially its host, Cirsium arvense. The species was observed in ruderal habitats in abandoned farms in the Równina Bełska plain, with the dominance of species of the class Artemisietea vulgaris. It grows in a humid usable meadow and a ditch in a tall-herb community of the Filipendulo-Geranietum association, with a high share of hygrophilous perennials of the Calthion alliance on the substrate rich in calcium carbonate at the locality in the Góry Kaczawskie Mts. In the Western Bieszczady Mts, it occurs on a stony roadside and in carr and meadow communities, in a tall-herb community of the Adenostylion alliariae alliance with a high quantitative share of dicotyledonous perennials of the class Molinio-Arrhenatheretea. Numerous similarities between the species composition in the community, especially the domination of Carduus personata, and the Carduuetum personatae (Hadač et al. 1969) association (Hadač 1969; Kliment 1989), differentiated at the locality of $O$. pallidiflora in the Sudetes (Kwiatkowski 2005), are observed.

The localities of $O$. pallidiflora recorded in the Lublin region are relatively sparse and highly threatened. They occur in usable or pastured meadows, often in the vicinity of arable fields. Cultivation intensification, including excessive fertilisation and mowing, is the main threat. Overgrowing and an increase in the abundance of herbaceous vegetation are the main threats posed to the populations occurring in abandoned farms. The locality in Wierzbica is situated within the Sołokija Dolina valley, a Natura 2000 sanctuary (PLB060021). The relatively most numerous locality of the species in Przeorsk in the Middle Roztocze plain at the foothill of Mt Łysa Góra as well as the adjacent xerothermic grassland should be protected, also because of the local occurrence of rare calcilophilous species. The population in the Bieszczady Mts is protected within the Bieszczady National Park and does not seem to be directly threatened. However, as a busy tourist trail has been developing nearby, some shoots may be destroyed mechanically by trampling or picking. The road near which the species grows is also used by Border Guard vehicles. Over ten developing shoots of $O$. pallidiflora that were broken by vehicle wheels were observed along the road edge in 2008. The locality in Nowe Rochowice is located within a private area in an extensive meadow. Changes in the usage method (cultivation, application of agrochemical agents) or any building developments within it pose serious threats to the population developing in the area. The locality in the Wyżyna Małopolska upland does not seem to be threatened at present. It is, however, located on the edge of an arable field where it can be exposed to the run-off of chemical agents.

Due to the instability of the localities occupied by the species and considerable fluctuations of the abundance at the sites, environmental monitoring of $O$. pallidiflora is recommended.

\section{ACKNOWLEDGEMENTS}

The authors thank Prof. Adam Zając for helpful comments on the manuscript.

This work was supported by the Ministry of Science and Higher Education (grant no. 3577/B/P01/2007/33).

\section{LITERATURE CITED}

BACIECZKO W. 1984. Rośliny rzadkie i chronione w szacie roślinnej stawów wiejskich na Pomorzu Szczecińskim. Zesz. Nauk. Akad. Roln. Szczecin 107: 3-9. (in Polish)

BACIECZKO W. 1991. Rzadkie i interesujące gatunki roślin doliny Płoni na Pojezierzu Barlineckim. Zesz. Nauk. Akad. Rol. Szczecin 149: 122-133. (in Polish)

BACIECZKO W. 1995. Studia porównawcze nad szatą roślinną występującą aktualnie w dolinie Płoni w stosunku do badań W. Libberta z 1938 roku. Rozpr. Akad. Roln. Szczecin 166: 1-112. (in Polish)

BACIECZKO W. 2002. Flora synantropijna Kołbacza koło Szczecina. Folia Univ. Agric. Stein, Agricultura 226(90): 5-28. (in Polish)

BACIECZKO W., MYŚLIWY M. 2005. Dolina Płoni na Pomorzu Szczecińskim - rejon obfitego występowania Orobanche pallidiflora (Orobanchaceae). Fragm. Flor. Geobot. Polonica 12(2): 267-273. (in Polish)

BACIECZKO W., MYŚLIWY M. 2008. The distribution of Orobanche pallidiflora Wimm. \& Grab. in Poland. Folia Univ. Agric. Aliment. Pisc. Zootech. 260(5): 5-14.

BECK VON MANNAGETTA G.R. 1890. Monographie der Gattung Orobanche. Bibl. Bot. 19: 1-275.

BECK VON MANNAGETTA G.R. 1930. Orobanchaceae L. In: Engler A. (eds), Das Pflanzenreich IV. (261): 1-348.

CELIŃSKI F. 1964. Rośliny naczyniowe Puszczy Bukowej pod Szczecinem. Pr. Komis. Biol. Pozn. Tow. Przyj. Nauk 29(2): 3-189. (in Polish)

CHATER A.O., WEBB D.A. 1972. Orobanche L. In: Tutin T.G. et al. (ed.), Flora Europaea 3: 286-293. Cambridge Univ. Press.

FABISZEWSKI J., KWIATKOWSKI P. 2002. Threatened vascular plants of the Sudeten Mountains. Acta Soc. Bot. Pol. 71(4): 339-350.

FOLEY M.J.Y. 1993. Orobanche reticulata Wallr. populations in Yorkshire (north-east England). Watsonia 19: 247-257. 
GILLI A. 1966. Bestimmungsschlüssel der mitteleuropäischen Varietäten und Form von Orobanche. Verh. der Zool.-Bot. Ges. in Wien 105/106: 71-181.

HADAČ E. (ed.). 1969. Die Pflanzengesellschaften des Tales "Dolina Siedmich prameňov" in der Belaer Tatra. Vegetacia ČSSR B2, Vydavatelstvo Slovenskej Akadémie Vied, Bratislava. pp. 1-343.

KĄCKI Z., DAJDOK Z., SZCZEŚSNIAK E. 2003. Czerwona lista roślin naczyniowych Dolnego Śląska. In: Z. Kącki (eds), Zagrożone gatunki flory naczyniowej Dolnego Śląska. pp. 9-65. Instytut Biologii Roślin, Uniwersytet Wrocławski, Polskie Towarzystwo Przyjaciół Przyrody "Pro Natura", Wrocław. (in Polish with English summary)

KLIMENT J. 1989. Carduuetum personatae Hadač et al. 1969 vo Vel'kej Fatre. Biol. 44: 451-457. (in Slovak)

KREUTZ C.A.J. 1995. Orobanche. The European broomrape species. 1. Central and northern Europe. Limburg.

KWIATKOWSKI P. 2000. Notatki florystyczne z Gór Kaczawskich i ich Pogórza (Sudety Zachodnie). Fragm. Flor. Geobot. Polonica 7: 105-116. (in Polish with English summary)

KWIATKOWSKI P. 2001. Zaraza bladokwiatowa Orobanche pallidiflora Wimm. \& Grab. w Sudetach Zachodnich. - Die Blaßblütige Sommerwurz Orobanche pallidiflora Wimm. \& Grab. in den westlichen Sudeten. Przyroda Sudetów Zachodnich 4: 3-8. (in Polish with German summary)

KWIATKOWSKI P. 2005. Stanowisko zarazy bladokwiatowej Orobanche pallidiflora Wimm. \& Grab. w Rudawach Janowickich. Przyroda Sudetów 8: 13-16. (in Polish with German summary)

ŁACHACZ A. 2002. Nowe stanowiska Orobanche pallidiflora (Orobanchaceae) w Puszczy Rominckiej. Acta Botanica Warmiae et Masuriae 2: 165-168. (in Polish with English summary)

MARKOWSKI R., BULIŃSKI M. 2004. Ginace i zagrożone rośliny naczyniowe Pomorza Gdańskiego. Acta Bot. Cassubica, Monogr. 1: 1-75. (in Polish with English summary)

MATUSZKIEWICZ W. 2006. Przewodnik do oznaczania zbiorowisk roślinnych Polski. Vademecum Geobotanicum. 3. Wydaw. Nauk. PWN Warszawa. (in Polish)

MĄDALSKI J. 1967. Rodzina Orobanchaceae, Zarazowate. In: Pawłowski B. (ed.), Flora Polska. Rośliny naczyniowe Polski i ziem ościennych 11, pp. 25-52. Państwowe Wydawnictwo Naukowe, Warszawa. (in Polish)

MEUSEL H., JÄGER E., RAUSCHERT S., WEINERT E. 1978. Vergleichende Chorologie der Zentraleuropäischen Flora. Karten 2: 412. Gustav Fischer, Jena.

MIREK Z., PIĘKOŚ-MIREK H., ZAJĄC A., ZAJĄC M. 2002. Flowering plants and pteridophytes of Poland - a checklist. In: Mirek Z. (ed.), Biodiversity of Poland. 1. Instytut Botaniki im. W. Szafera, Polska Akademia Nauk, Kraków, pp. 1-442.

NOWAK A., NOWAK S., SPAŁEK K. 2003. Red list of vascular plants of Opole province. Opole Scientific Society, Nature Journal 36: 5-20.
NOWAK A., NOWAK S., SPAŁEK K. 2008. Red list of vascular plants of Opole province - 2008. Opole Scientific Society, Nature Journal 41: 141-158.

PARUSEL J.B., WIKA S., BULA R. (ed.) 1996. Red list of Upper Silesian vascular plants. In: Parusel J.B. (ed.), Centrum dziedzictwa przyrody Górnego Śląska. Raporty, Opinie 1: 8-42 . Katowice.

ROTHMALER W., JÄGER E.J., WERNER K. 2002. Exkursionsflora von Deutschland - Kritischer Band 4. Spectrum Akademischer Verlag, Berlin.

RUTKOWSKI L. 1997. Rośliny naczyniowe - Tracheophyta. In: J. Buszko, K. Kasprzyk, T. Pawlikowski, A. Przystański, L. Rutkowski (eds), Czerwona lista roślin i zwierząt ginących i zagrożonych w regionie kujawsko-pomorskim. Acta Univ. Nicolai Copernici. Biologia 53, Supl. Nauk. Mat.-Przyr. 98: 5-20. Toruń. (in Polish with English summary)

SZAFER W., KULCZYŃSKI S., PAWŁOWSKI B. 1924. Rośliny polskie. Książnica-Atlas, Warszawa-Lwów. (in Polish)

TZVELEV N.N. 1981. Orobanchaceae. In: A.A. Fedorov (ed.), Flora evropeyskoy chastii SSSR 5: 317-335. Izdatel'stvo Nau$\mathrm{ka}$, Leningrad. (in Russian)

UHLICH H., PUSCH J., BARTHEL K.J. 1995. Die Sommerwurzarten Europa: Gattung Orobanche. Westarp-Wiss., Magdeburg.

ZAJĄC A. 1978. Założenia metodyczne "Atlasu rozmieszczenia roślin naczyniowych w Polsce”. Wiad. Bot. 22(3): 145-155. (in Polish)

ZAJĄC A., ZAJĄC M. (eds). 2001. Atlas rozmieszczenia roślin naczyniowych w Polsce. Nakładem Pracowni Chorologii Komputerowej Instytutu Botaniki Uniwersytetu Jagiellońskiego, Kraków. (in Polish with English summary)

ZARZYCKI K., SZELĄG Z. 2006. Red list of the vascular plants in Poland. In: Z. Mirek, K. Zarzycki, W. Wojewoda, Z. Szeląg (eds), Red list of plants and fungi in Poland. pp.: 9-20. W. Szafer Institute of Botany, Polish Academy of Sciences, Kraków.

ZARZYCKI K., TRZCIŃSKA-TACIK H., RÓŻAŃSKI W., SZELĄG Z., WOŁEK J., KORZENIAK U. 2002. Ecological indicator values of vascular plants of Poland. In: Mirek Z. (ed.), Biodiversity of Poland 2, p. 183. W. Szafer Institute of Botany, Polish Academy of Science, Kraków.

ZÁZVORKA J. 2000. Orobanchaceae - zarazovite. In: Slavik B. (ed.), Kvetena Česke Republiky 6, Academia, Praha, p. 477-513. (in Czech).

ŻUKOWSKI W., JACKOWIAK B. 1995. Lista roślin naczyniowych ginących i zagrożonych na Pomorzu Zachodnim i w Wielkopolsce. In: Żukowski W., Jackowiak B. (eds), Ginące i zagrożone rośliny naczyniowe Pomorza Zachodniego i Wielkopolski. Publications of the Departament of Plant Taxonomy of Adam Mickiewicz University in Poznań 3: 9-96. Bogucki Wydaw. Nauk., Poznań. (in Polish with English summary) 